\title{
かご形誘導電動機の負荷時電磁振動に及ぼす スロット数組合せと斜めスロットの影響
}

\author{
正員 廣 塚 功 (中部大学) \\ 正員坪井和男 (中部大学)
}

Effects of Slot-Combination and Skewed Slot on the Electromagnetic Vibration of A Squirrel-Cage Induction Motor under Load Conditions.

\author{
Isao Hirotsuka, Member (Chubu University) \\ Kazuo Tsuboi, Member (Chubu University)
}

\begin{abstract}
A squirrel-cage induction motor (abbr. IM) produces the electromagnetic vibration and the electromagnetic noise by the interaction between many harmonic fluxes in the air gap. Recently, reduction of such vibration and noise has become important subject from the standpoint of environmental improvement. The electromagnetic vibration caused by IM has been studied for many years and its basic phenomena have been analyzed. However, the electromagnetic vibration under load conditions has not been analyzed sufficiently.

In this paper, the effects of slot-combination and skewed slot on the dominant electromagnetic vibration under load conditions are theoretically and experimentally studied. First, general equations of electromagnetic force waves are derived in order to discuss easily, and the characteristics of the force waves for slot-combination and skewed slot are theoretically clarified. Next, the electromagnetic vibration for the several kinds of poles, rotor slots and skewed angles are measured, taking the effect of natural frequency of the motor into consideration. The effects of slot-combination and skewed slot on these measured vibration are characterized by the proposed theory.
\end{abstract}

キーワード：誘遒電動機，電磁振動，スロット数組合せ，斜めスロット

\section{1.まえがき}

三相かご形誘導電動機（以下, IMと略記）は, その構 造上，ギャップ中に基本波を含めた高調波磁束が存在する ので, その大小の差はあるが, 電磁騒音の原因となる電磁 振動を発生する。IMの電磁振動については, 古くから多 数の研究が行われており(1) 〜(5)，電磁振動は主にギャッ プ中の基本波を含めた高調波磁束の相互作用による電磁力 波が固定子わくを振動させることにより発生することが明 らかにされている。しかし, 負荷時における電磁振動およ び電磁騒音は, IMに接続される負荷機構, 設置条件の影 響を受けるため, 極めて難解な問題であり, 未解明な部分 が多数存在している。

以上のような背景により, 本諭文では, IM単体の負荷 時電磁振動に及ぼすスロット数組合せおよび斜めスロット の影響について理論的かつ実験的に検討している。すなわ ち, 前論文において既に導出した理論 ${ }^{(6)}$ に基づき, 負荷
時に生じる顕著な電磁力波のスロット数組合せに対する特 徵を明確に示している。また, 前論文の理論 ${ }^{(6)}$ を整理拡 張し, 斜めスロットが顕著な負荷時電磁力波に及ぼす影響 を, 無負荷時の場合と対比して理論的に考察している。次 に，極数の異なる2種類の固定子にスロット数の異なる 19 種類の回転子を組み合わせた供試機を用いた詳細なる実験 結果に基づき，スロット数組合せに対する顕著な電磁振動 の発生状況を明確にしている。また, 顕著な電磁振動に対 する斜めスロットの効果を実験的に考察している。その結 果, スロット数組合せに対する顕著な電磁振動の発生の特 徵および斜めスロットによる電磁振動の㧕止効果などを明 らかにしている。なお，本論文は回転機研究会などに発表 した内容 ${ }^{(7)} \sim$ (10) を更に整理加筆したものである。

\section{2. 負荷時に生じる電磁力波}

〈2・1 顕著な電磁力波顕著な負荷時電磁振動の発生 原因となる電磁力波の一般式の導出については既に文献 
（6）にまとめてあるので，ここでは，スロット数組合せ に対する電磁力波の発生の特徵および斜めスロットと電磁 力波との関倸について考察するのに必要な電磁力波の一般 式をまとめておく。なお，実機における電磁振動は，磁気 飽和, 回転子のバ一間電流および機械的加工精度に起因す る偏心などによって影響を受けるが、ここでは, 特に顕著 な電磁振動の発生原因となり得る電磁力波のみに対して検 討することとしている。

ギャップ中の磁束として, 固定子および回転子起磁力, およびギャップパーミアンスに起因する固定子磁束密度bs および回転子磁束密度brを考える。電磁振動の発生原因々 なる顕著な電磁力波 $f r$ は, その発生周波数 $f_{M}$ が比較的高 いこと，そのモードMが比較的小さいこと，および主要な 高調波磁束に起因していることなどを勘案すれば， $b s$ と $b r$ との積に比例する。したがって，frは（1）式のように表 わすことができる ${ }^{(6)}$ 。

$$
\begin{aligned}
& f r s r=\sum_{\nu e^{\prime}} \sum_{k s} \sum_{k r} \sum_{k s^{\prime}} \sum_{k r^{\prime}} f_{r s n u e^{\prime} k s k r k s^{\prime} k r^{\prime}} \\
& \times\left(\operatorname { c o s } \left[\left\{\frac{k r-k r^{\prime}}{p^{\prime}} n(1-s)\right\} \omega t\right.\right. \\
& \left.-\left\{\left(\nu e^{\prime}+k s n s+k r n\right)-\left(p^{\prime}+k s^{\prime} n s+k r^{\prime} n\right)\right\} \phi\right] \\
& +\cos \left[\left\{\frac{k r+k r^{\prime}}{p^{\prime}} n(1-s)+2\right\} \omega t\right. \\
& \left.\left.-\left\{\left(\nu_{e}^{\prime}+k s n s+k r n\right)+\left(p^{\prime}+k s^{\prime} n s+k r^{\prime} n\right)\right\} \phi\right]\right) \\
& \text {........................... (1) }
\end{aligned}
$$

\begin{tabular}{|c|c|c|}
\hline \multirow{2}{*}{ 分 } & \multirow{2}{*}{ 発生周波数 $f_{M}$} & モードM (複合同順) \\
\hline & & $\left(b_{s} \omega\right.$ 次数: $\left.v_{s}{ }^{\prime}\right) \pm\left(b_{r} \sigma\right.$ 次数: $\left.v_{r}{ }^{\prime}\right)$ \\
\hline \multirow{2}{*}{ (1) } & \multirow{2}{*}{$\frac{K n}{p^{\prime}}(1-s)-2$}$f$ & {$[I]:\left|\left(v_{e}^{\prime}\right)+\left(p^{\prime}+L n_{s}-K n\right)\right|$} \\
\hline & & {$[\Pi]:\left|\left(v_{e}{ }^{\prime}+L n_{s}-K n\right)+\left(p^{\prime}\right)\right|$} \\
\hline \multirow{2}{*}{ (2) } & \multirow{2}{*}{$\frac{K n}{p^{\prime}}(1-s)$}$f$ & [I] : | $\left(v_{e}^{\prime}\right)-\left(p^{\prime} \pm L n_{s} \mp K n\right)$ \\
\hline & & [II]: $\left|\left(\nu_{e}^{\prime} \pm L n_{s} \mp K n\right)-\left(p^{\prime}\right)\right|$ \\
\hline \multirow[b]{2}{*}{ (3) } & \multirow{2}{*}{$\frac{K n}{p^{\prime}}(1-s)+2$}$f$ & [ I ] : $\left|\left(v_{e}^{\prime}\right)+\left(p^{\prime}-L n_{s}+K n\right)\right|$ \\
\hline & & [II]: $\left|\left(\nu_{e}^{\prime}-L n_{s}+K n\right)+\left(\phi^{\prime}\right)\right|$ \\
\hline
\end{tabular}

（1）式において，固定子扝よび回転子スロット高調波の

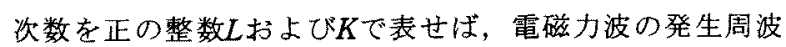
数 $f_{M}$ おびモモードMを表 1 のようにまとめることができ る。同表より明らかなように，負荷時においては，同一の

表1 顕著な電磁力波

Table 1. Dominant electromagnetic radial forces.
$f_{M} に 2$ 種類の電磁力波を生じることとなる。すなわち，無 負荷時にも顕著上なる電磁力波 [I］と負荷時にのみ顕著 となる電磁力波 [I] とを生じる。なお，分類番号は後述 の検討の便宜上つけた番号である。

〈2·2〉スロット数組合せに対する特緐表1の高調波 次数に，後述の供試機に対応した数值を代入すると，負荷 時に生じる特に顕著な電磁力波を表 2 のようにとめるこ とができる。同表においては， $v_{\ell}^{\prime}=p^{\prime} ， L=K=1 ， 2 お よ$ び，M=1，2および3となる電磁力波のみを回転子スロッ 卜数および極数に対してまとめてある。また，表2は，同 一周波数に同一のモードの $2 つ の$ 電磁力波 [I ] および

\begin{tabular}{|c|c|c|c|c|c|c|}
\hline \multirow{2}{*}{$n$} & \multirow{2}{*}{$\begin{array}{l}n \\
\infty \\
\text { 例 }\end{array}$} & \multirow{2}{*}{$\begin{array}{l}4 \text { 極・6 } \\
\text { 極共通 } \\
\text { (2) }\end{array}$} & \multicolumn{2}{|c|}{4 極 IM } & \multicolumn{2}{|c|}{6 極 IM } \\
\hline & & & (1) & (3) & (1) & (3) \\
\hline$n_{S}-9$ & 27 & & & & & $3(1)$ \\
\hline$n_{S}-8$ & 28 & & & & & $2(1)$ \\
\hline$n_{S}-7$ & 29 & & & $3(1)$ & & $1(1)$ \\
\hline$n_{S}-6$ & 30 & & & $2(1)$ & & \\
\hline$n_{s}-5$ & 31 & & & 1(1) & & $1(1)$ \\
\hline$n_{S}-4$ & 32 & & & & & $\begin{array}{l}2(1) \\
2(2)\end{array}$ \\
\hline$n_{S}-3$ & 33 & $3(1)$ & & $\begin{array}{l}1(1) \\
2(2)\end{array}$ & & $\begin{array}{l}3(1) \\
3(3)\end{array}$ \\
\hline$n_{S}-2$ & 34 & $2(1)$ & & $\begin{array}{l}2(1) \\
2(3)\end{array}$ & & $2(2)$ \\
\hline$n_{S}-1$ & 35 & $\begin{array}{l}1(1) \\
2(2) \\
3(3)\end{array}$ & & $\begin{array}{l}3(1) \\
2(2) \\
1(3)\end{array}$ & & $3(3)$ \\
\hline$n_{S}$ & 36 & & & & & \\
\hline$n_{S}+1$ & 37 & $\begin{array}{l}1(1) \\
2(2) \\
3(3)\end{array}$ & $\begin{array}{l}3(1) \\
2(2) \\
1(3)\end{array}$ & & $3(3)$ & \\
\hline$n_{s}+2$ & 38 & $2(1)$ & $\begin{array}{l}2(1) \\
2(3)\end{array}$ & & $2(2)$ & \\
\hline$n_{s}+3$ & 39 & $3(1)$ & $\begin{array}{l}1(1) \\
2(2)\end{array}$ & & $\begin{array}{l}3(1) \\
3(3) \\
\end{array}$ & \\
\hline$n_{s}+4$ & 40 & & & & $\begin{array}{l}2(1) \\
2(2)\end{array}$ & \\
\hline$n_{s}+5$ & 41 & & $1(1)$ & & $1(1)$ & \\
\hline$n_{S}+6$ & 42 & & $2(1)$ & & & \\
\hline$n_{S}+7$ & 43 & & $3(1)$ & & $1(1)$ & \\
\hline$n_{s}+8$ & 44 & & & & $2(1)$ & \\
\hline$n_{s}+9$ & 45 & & & & $3(1)$ & \\
\hline
\end{tabular}
[II] が発生することも意味している。同一周波数に原因 の異なる2種類の電磁力波を生じる場合，2つの電磁力波の ベクトル和がその周波数における合成電磁力波とな る(11)。負荷が変化すれば，2つの電磁力波の大きさのみ ならず，2つの電磁力波間の位相差も変化するので，合成 電磁力波は負荷に対して単調增加もしくは単調隇少すると は限らない。

表2より明らかなように，極数が少なく，固定子スロッ 卜数に近い回転子スロット数の場合，多くの顕著な電磁力 波を生じる傾向にある。極数の倍数となる回転子スロット

表2 低次のスロット高調波による顕著な電磁力波

Table 2. Dominant electromagnetic forces caused by lower slot-harmonics.

注：例えば，「3(1)」の表記は，表1においいて，L=K

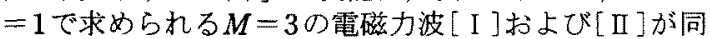
一周波数に生じることを意味する。 


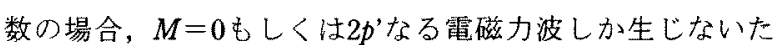
め，表2においては空白となっている。なお，機械系の共 振の影響扝よび固定子起磁力高調波などにより，表2に示 した以外の電磁力波に起因して，顕著な電磁振動を発生す る場合がある。また，同表は，例えば，文献（3）を参照 寸れば作成でき，文献（5）の表 2 と形の上でまったく同一 となっている。しかし，無負荷時のみならず責荷時に生じ る電磁力波も含めて表していることが異なっており，本論 文で初めて明示したものである。

〈2·3〉斜めスロットによる抑止効果図1に, 電磁力 波［I］および［II] の発生原因となる高調波次数関倸な どのイメージ図を示す。同図は，これらの電磁力波の発生 過程の考え方を示すのみならず，前論文（6）を更に拡張 し，斜めスロットがこれらの電磁力波に及ぼす影響を考虑 して図式的にまとめたものである。

回転子導体に斜めスロットを施した場合，回転子導体に 誘導される基本波を含めた $v_{p}{ }^{\prime}$ 次調波の電圧は，（2）式 で示される高調波次数の斜めスロット係数に比例して減少 する ${ }^{(12)}$

$$
K_{s v p^{\prime}}=\frac{n \sin \left(\nu_{p}^{\prime} \sigma_{r} \pi / n\right)}{v_{p}^{\prime} \sigma_{r} \pi}
$$

ここで, $K_{s v p^{\prime}}: v_{p}$ '次調波の斜めスロット係数,

$\sigma_{r}$ : 回転子スロットピッチに対する斜めスロッ

卜比。

従って，単位面積当たりの電磁力波は，回転子導体の高調 波電流がその高調波次数の斜めスロット俰数に比例して減 少することから，回転子磁束の高調波次数の斜めスロット 係数の絶対値に比例することとなる。

電磁力波 [I］の発生過程および斜めスロットがこの電 磁力波に及ぼす影響を図1（a）に示したように考えて考察 する。すなわち，無負荷時および負荷時を問わず，固定子 起磁力とギャップパーミアンスとの積による固定子磁束の $v_{p}^{\prime}\left(=p^{\prime} \pm L n_{s}\right)$ 次調波により，回転子導体にはv 次調 波の電流が流れる。電磁力波 [I] のうち，特に顕著とな る電磁力波は，この $v_{p}$ '次調波の電流に起因した回転子高 調波磁束と固定子の基本波磁束との相互作用により生じる ので，回転子磁束を作る固定子磁束の高調波次数 $v p{ }^{\prime}$ の斜 めスロット係数の絶対值に比例すると考えられる (5)。

また, 電磁力波 [I] $＼mathrm{~ の 発 生 過 程 お よ ひ ゙ 斜 め ス ロ ッ ト か ゙ ~}$ この電磁力波に及ぼす影響を図1（b）に示したように考え て考察する。すなわち，負荷時には回転子導体に，前述の $\nu$ p'次調波電流に加え, すべり周波数の基本波電流が流机 る。この基本波電流によって $v_{q}^{\prime}\left(=p^{\prime} \pm K n\right)$ 次の回転子 磁束を生じるこの回転子磁束により固定子巻線には $v_{q}^{\prime}$ 次の“は孖返り電流”（13）が流れ，は㛊返り電流に上る $v_{s}^{\prime}\left(=v_{q}^{\prime} \pm L n_{s}\right) \cdot$ 次の固定子磁束を生じる。この磁束と 回転子の基本波磁束との相互作用により電磁力波 [II] を 生じる。回転子導体が斜めスロットとなっている場合, 回 転子導体に流れる基本波電流は基本波に対する斜めスロッ 卜係数に比例して減少し，固定子巻線へのは视返り電流も v $q^{\prime}$ 斜めスロット係数に比例して隇少する。基本波の斜 めスロット係数がほぼ1であることから，電磁力波 [II] は固定子へのは称返り電流の次数 $\nu q^{\prime}$ 斜めスロット係数 の絶対值にほぼ比例してして減少すると考えられる。な お, 電磁力波 [I] は, 負荷時においても前述の無負荷の 場合と同様であると考えている。

以上をまとめると，回転子に斜めスロットを施すことに より, 負荷時において, 電磁力波 [I] は回転子磁束を作 る固定子高調波磁束の斜めスロット係数の絶対值にほぼ比 例して隇少する。また，電磁力波〔匹]は，固定子へのは ね返り電流の次数の斜めスロット倸数の絶对值にほぼ比例 して減少することとなる。なお，前述のように，負荷時に おいては同一周波数に原因の異なる2種類の電磁力波 [I ] および [ П] が生じ，その周波数に生じる電磁力波 は電磁力波 [I ] と［II] との合成電磁力波となる ${ }^{(8)}$ 。 従って，電磁力波に及ぼす斜めスロットの影響を考察する 場合, これら2つの電磁力波の大きさのみならず位相も考 虑しなくてはならないので，特定の高調波次数の斜めスロ ット係数の絶対值に比例して堿少するとは限らない。な お，2つの電磁力波の位相が関倸する電磁力波についての

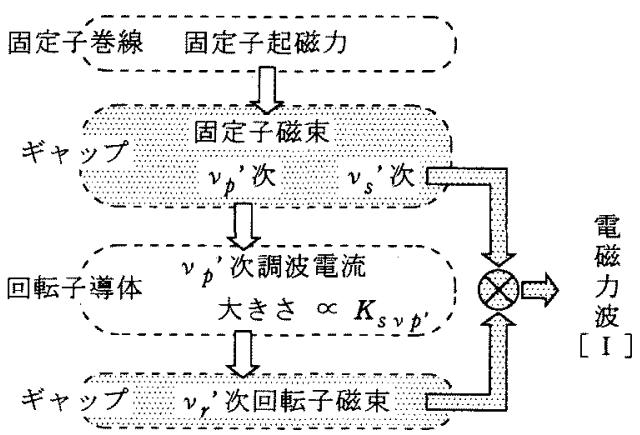

(a) 電磁力波 $[\mathrm{I}]$

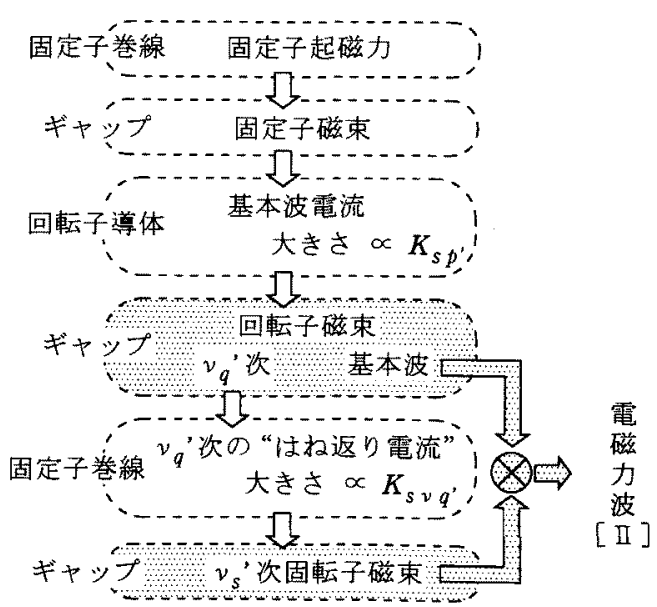

(b) 電磁力波 [I]

図 1 顕著な電磁力波の発生過程

Fig. 1. Process of the generation on dominant electromagnetic force under load conditions. 
詳細な検討は今後の課題としたい。また，IMの電源側の インピーダンスを変更した場合，IM のの流入電流の高調 波成分および電磁振動が変化することを確認しているが, はね返り電流と電磁振動との関係の更に詳細な検討は今後 の課題としたい。

\section{3. 供試機の仕様および実験方法}

供試機の仕様を表3に示す。スロット数組合せに対する 電磁振動の発生状況を測定する場合には，4極および6極の 固定子に19種類の異なるスロット数の回転子（いずれも斜 めスロットを施していない）を組合せた供試機を用いてい る。また，電磁振動に及ぼす斜めスロットの影響を調べる 場合には，4極の固定子に，スロット数27および35でそれ ぞれの回転子に対し $\sigma_{r}=0.0,0.3,0.7,1.0$ なる斜めス口 ット比の回転子を組合わせた供試機を用いて実験を行っ た。表3においては，各々の供試機の室温時に測定した主 な固有振動数も示してある。625Hzおうよび650Hzは回転子 の1次曲げの固有振動数であり，他の周波数は固定子わく および固定子鉄心が多角形変形する固有振動数である。こ

表3 供試機の仕様

Table 3. Specification of the test machine.

\begin{tabular}{|c|c|c|}
\hline 相 & \multicolumn{2}{|c|}{3} \\
\hline 極 & 4 & 6 \\
\hline 定 格 出 力 & $1.5 \mathrm{~kW}$ & $0.75 \mathrm{k} \mathrm{W}$ \\
\hline 定格 周 波数 $f n$ & \multicolumn{2}{|c|}{$60 \mathrm{~Hz}$} \\
\hline 定 格 電 圧 $V n$ & \multicolumn{2}{|c|}{$200 \mathrm{~V}$} \\
\hline 巻 線 形 式 & \multicolumn{2}{|c|}{ 分布全節 巻 } \\
\hline 固定子スロット数 $n_{S}$ & \multicolumn{2}{|c|}{36} \\
\hline 回転子スロット数 $n$ & \multicolumn{2}{|c|}{$27 \sim 45$} \\
\hline $\begin{array}{l}\text { 回転子スロットに対す } \\
\text { る斜めスロット比 } \sigma r\end{array}$ & \multicolumn{2}{|c|}{$0.0,0.3,0.7,1.0$} \\
\hline $\begin{array}{l}\text { 主な固有振動数 } \\
\text { (静止冷温時) }\end{array}$ & $\begin{array}{c}625, \quad 1700, \\
3300, \quad 4000 \\
\mathrm{~Hz}\end{array}$ & $\begin{array}{r}650,1550, \\
1625,3150, \\
3975 \mathrm{~Hz}\end{array}$ \\
\hline
\end{tabular}

但し，スロット数組合せに対する検討には $\sigma_{r}=0.0$ の みの回転子使用, 斜めスロットの影響に対する検討 には $=27$ および35の回転子のみを使用した。

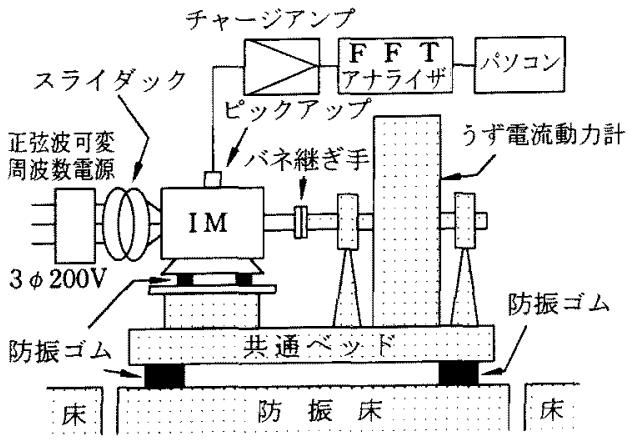

図 2 実験装置の構成図

Fig. 2. Arrangement of experimental apparatuses.
の固有振動数は実験時の温度上昇により多少変化すること を確認している。

実験装置の構成を図2に示す。IMを弾性ゴム足のついた 強固な共通ベース上に据え, 回転方向に堅牢で軸方向に柔 軟なカップリング，床と共通ベースとの間の防振ゴム，実 験装置が設置されている床と他の床との切り離しなど, 多 数の防振措置を施している。電源には正弦波可変周波数電 源を用いており，供試機の始動時異常現象を避けて起動で きるようにするとともに, 印加電圧 $V$ と周波数 $f$ と比を任 意に変更できるようにしている。半径方向の電磁振動を, IMのほぼ中央上部に取り付けた加速度ピックアップにて 検出している。これをFFTアナライザで解析し, 振動加速 度 $f a[\mathrm{G}]$ ，発生周波数 $f v[\mathrm{~Hz}]$ および $10 \mathrm{kHz}$ までの振動 加速度の全奏効値Fva [G] をパソコンに転送してデータ 処理を行っている。負荷状態を定格トルクに対する比（以 下，負荷率と略記）Lpで定義しており，無負荷時において は $L p=0 \%$ であり，全負荷時に $L p=100 \%$ である。なお， IMは負荷装置に接続されているので， $L p=0 \%$ と表した場 合であっても，IMの負荷状態は厳密には無負荷ではな い。しかし，多数の予備実験の結果， $L p=0 \%$ で振動測 定值は, IM単体での测定値とほぼ一致していることか ら，Lp=0\%と表記している。

$f v か ゙ L p に$ 対して变化するので, faは機械系の共振の影響 を著しく受ける場合がある。こうした機械系の共振の影響 を避けるためには，個々の振動成分に対してfvを一定とす る実跒を行う必要がある。電磁振動に及ぼすスロット数組 合せの影響を調べるための実験を行う場合には，IMの実 際の使用状態を勘案して, 印加電圧を定格電圧，周波数を 定格周波数に保って行った。電磁振動に及ぼす斜めスロッ トの影響を調べるための実験を行う場合には，個々の振動 成分に対して機械系の共振の影響をできるだけ受けないよ う，fvを一定に保つように，印加電圧の周波数 $f$ を調整し， かつ，ギャップ磁束をほぼ一定とするため，V/fの比を定 格電圧 $V n$ と定格周波数 $f n$ との比 $V n / f n=200 \mathrm{~V} / 60 \mathrm{~Hz}$ 五一 定となるようにVも調整している。なお，本論文では，振

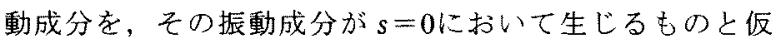
定した場合の $f v$ を $f n$ 倍数として表している。

\section{4. 実験結果および険討}

図3に, $p^{\prime}=2, n=29$ における電磁振動の測定結果を示 寸。同図より明らかなように, $p^{\prime}=2, n=29$ の場合, $L p=$

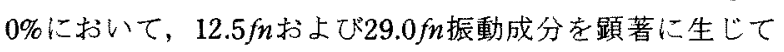
いる。これらの振動成分の発生周波数 $f v$ は, 負荷時に顕 著となる $70.5 \mathrm{fn}$ 振動成分も含め, 負荷の増加と共に減少 し, その振動加速度 $f a$ も変化している。12.5 $f n$ 振動成分 は, $L p=0 \% に$ にいて顕著であるが，負荷の増加とともに 振動加速度 $f a$ が単調增加する。表 2 との対応より, $12.5 \mathrm{fn}$ 振動成分の発生の主原因は, $L p=0 \%$ において, $M=1$ の電 磁力波 [I ] である。L $L$ を増加すると、この電磁力波 [I ] と同一周波数で同一モードの固定子高調波磁束と回 


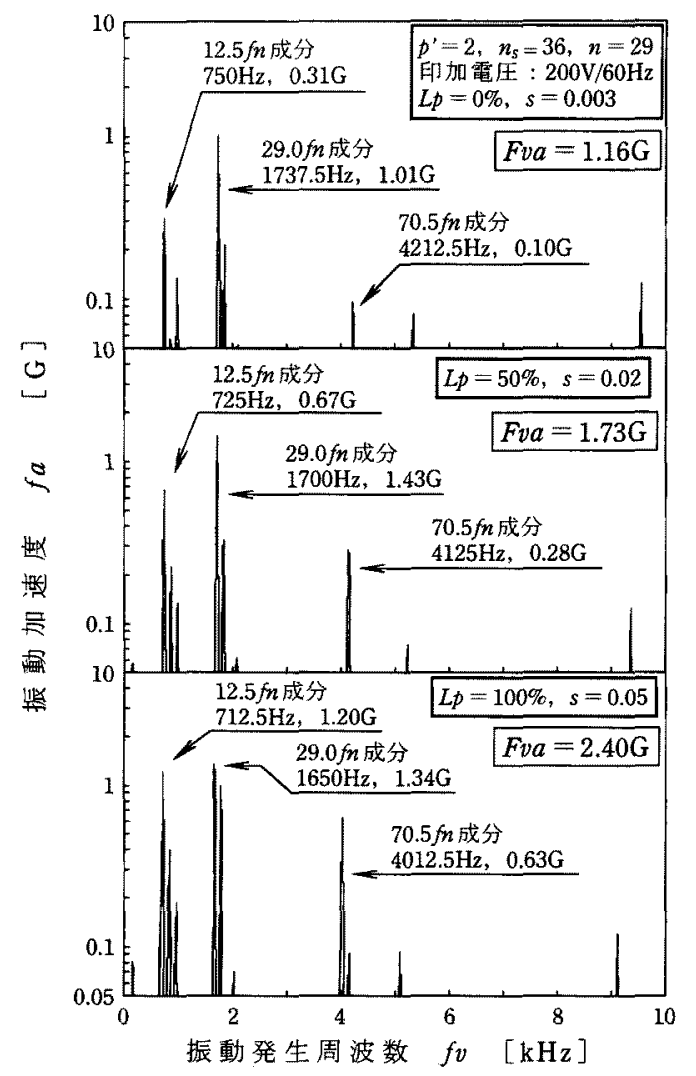

図3 顕著な電磁振動 $\left(n=29, \quad \sigma_{r}=0.0\right)$

Fig. 3. Measured dominant electromagnetic vibration. $\left(n=29, \quad \sigma_{r}=0.0\right)$

転子基本波磁束との相互作用により生じる電磁力波 [II] により単調に増加している。29.0 f $n$ 振動成分は， $L p=50 \%$ まで増加した後， $L p=100 \%$ とすると減少する。これは， 表3に示した本供試機の $1700 \mathrm{~Hz}$ における固有振動数の存在 により，機械系の共振の影響を受けたものと考えている。 $70.5 f n$ 振動成分は， $L p=0 \%$ で問題とならないが, 負荷 の増加とともに顕著となる振動成分である。この振動成分 も，29.0 fn振動成分と同様に，機械系の共振の影響を受け て顕著に生じたものと考えられる。なお，このスロット数 組合せの場合，Lpを增加すると，多くの振動成分のfaが増 大するため，振動加速度の全実効值Fvaも增大している。

〈4.1〉電磁振動に及ぼすスロット数組合せの影響４極 および6極IMにおける $n$ に対する影著な振動成分の発生状 況を図4に示す。同図において，（a）は $p^{\prime}=2 ，$ （b）は $=3$ の場合であり，横軸は $n$ ，縌軸はf $v$ おび $f_{M}$ である。図 中の「○」印は発生している各振動成分を表し，faの大き さにより「○」印の大きさを3段階に変えている。また， これらの図中の斜線は表1に示した $f_{M}$ を示している。特に 顕著な振動成分の発生原因などを表4および表5に示す。 Lpの増加に伴い,これらの図表に示したほとんどの振動成 分は增大し，顕著な振動成分が增える傾向にある。これ は, 前述のように, 無負荷時には1種類の電磁力波しか生
じないが，負荷の増大と共に，電磁力波［I］が増大し， 顕著な電磁振動の発生に寄与したためと考えている。な お，同図のLp=0\%の場合は，文献（5）の図2（a）および （b）に対応するが，IMを電力計へ接続した影響および測 定時の温度状態などの測定条件の差翼により, 若干発生状 況が異なったものと考えている。

各極数每にスロット数組合せによる電磁振動の発生の特 徵をまとめると以下のようである。

（1）4極（ $p^{\prime}=2 ） I M の$ 場合（図4（a）および表4）

回転子スロット数 $n$ が極数 $2 p^{\prime}$ の倍数となる回転子, すな

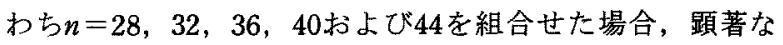
振動を生じない傾向にある。これは, 表2より明らかなよ うに、これらのれではモードが小さな電磁力波を生じない ためであると考えられる。

$n か ゙$ 極対数 $p^{\prime}$ 倍数となる（極数 $2 p^{\prime}$ の倍数となる場合を 除く）回転子を組み合わせた場合，K=1において顕著な 電磁振動を生じる傾向にある。特に， $n=30,34,38$ にお いては，表2に示したように，モード $M=2$ となる電磁力波 により特に顕著な電磁振動を生じている。これは，nがか'

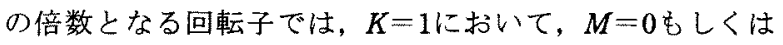

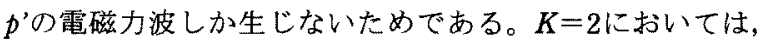
表2に示したように，モードの小さな電磁力波を生じない ため、頭著な電磁振動を生じない傾向にあると考えられ る。K=3においては， $n=34$ および38の場合のみ， $M=2$ となる電磁力波を生じるため, 顕著な電磁振動を生じてい る。

（2）6極（ $p^{\prime}=3 ） I M の$ 䭪合（図4（b）および表5）

4極IMの場合とは異なり，ほとんどの回転子スロット数

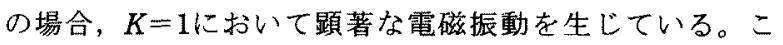
れら顕著な電磁振動は, いずれも供試機の固有振動数とほ ぼ一致した周波数で生じていることから，機械系の共振の 影響を著しく受けているものと考えられる。

回転子スロット数 $n$ が極対数p'の倍数となる回転子を組

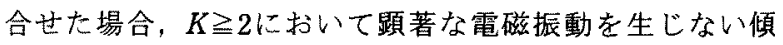

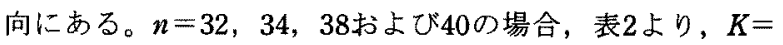
$2 に お い て ~ M=2$ となる電磁力波に起因した顕著な電磁振動 を生じている。これらの発生周波数は, 供試機の固有振動 数に近い1400Hz近辺であり，機械系の共振の影響をかな り受けているものと考えられる。このため, 負荷の増加と 共に振動発生周波数が减少し, 共振周波数から遠ざかるた め, $n=38$ 場合を除き, 振動加速度が減少していること

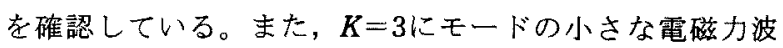
を生じるが，特に顕著な振動成分を生じていない。このよ うに，本論文で用いた6極IMでは，Lpを增加した場合， モードの小さな電磁力波の発生周波数は機械系の共振周波 数から遠ざかるため，0.1G以上の顕著な振動成分が增加し にくい傾向にあることが実験的に明らかとなった。

以上の実験結果より，極数およびスロット数組合せによ る電磁振動の発生の特徴は, 表2に示したモードの小さな 電磁力波の発生状況と類似した傾向であることが明らかと 
なった。またそその電磁力波の発生周波数と供試機の固有 振動数とが近くなる場合には十分な注意を要することなど も明らかとした。なお，実験の結果，電磁振動を生じにく いスロット数組合せが存在することを明らかとしたが，こ れらのスロット数組合せにおいては始動時の異常トルクが 非常に大きくなり (14)，場合によっては始動不可能なも のもあることに留意されたい。また，図4において， $f_{M}$ と 一致しない周波数に顕著な電磁振動を生じる場合も見られ る。これらは供試機の固有振動数近辺に生じている場合が 多く，表2に示した以外の電磁力波により生じているもの と考えられるが，詳細については今後の課題としたい。 図5に，回転子スロット数nに対する振動加速度の全実効 值Fvaを示す。多くのスロット数組合せにおいて, 負荷の 增加とともにFvaは增大している。これは，各スロット数 組合せにおいて生じる振動成分の多くがLpの増加と共に増 大したためである。しかし，例えば， $p^{\prime}=2, n=44$ の場合 および $p^{\prime}=3, n=40$ 場合などでは，Lpの增加に伴いFva は減少している。 $p^{\prime}=2, n=44$ の場合，88fn成分および $110 f n$ 成分が顕著に生じている。これらの振動成分が機械 系の共振の影響に上り減少するため，全実効值も減少して いることを確認している ${ }^{(15)}$ 。また，特に顕著な振動成 分を生じていない場合，すなわち，4極IMに極数の倍数上
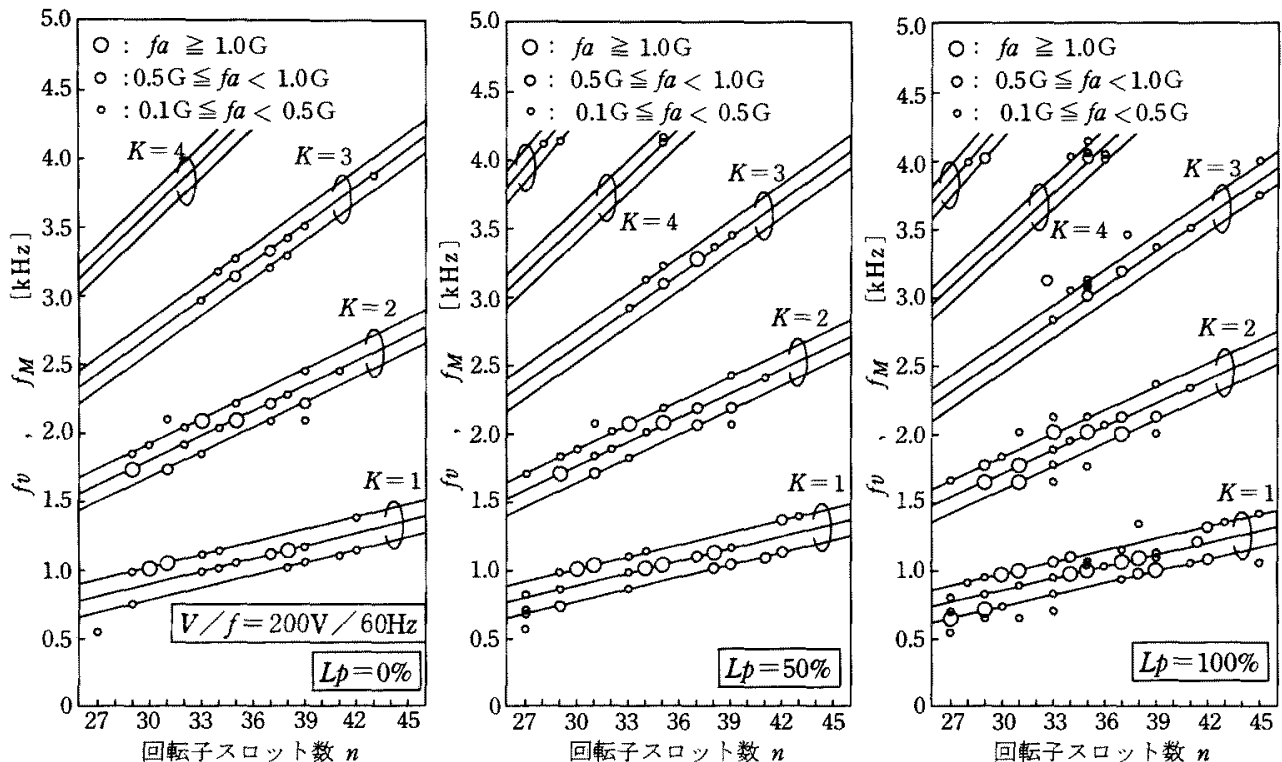

(a) 4 極 IM $\left(p^{\prime}=2\right)$
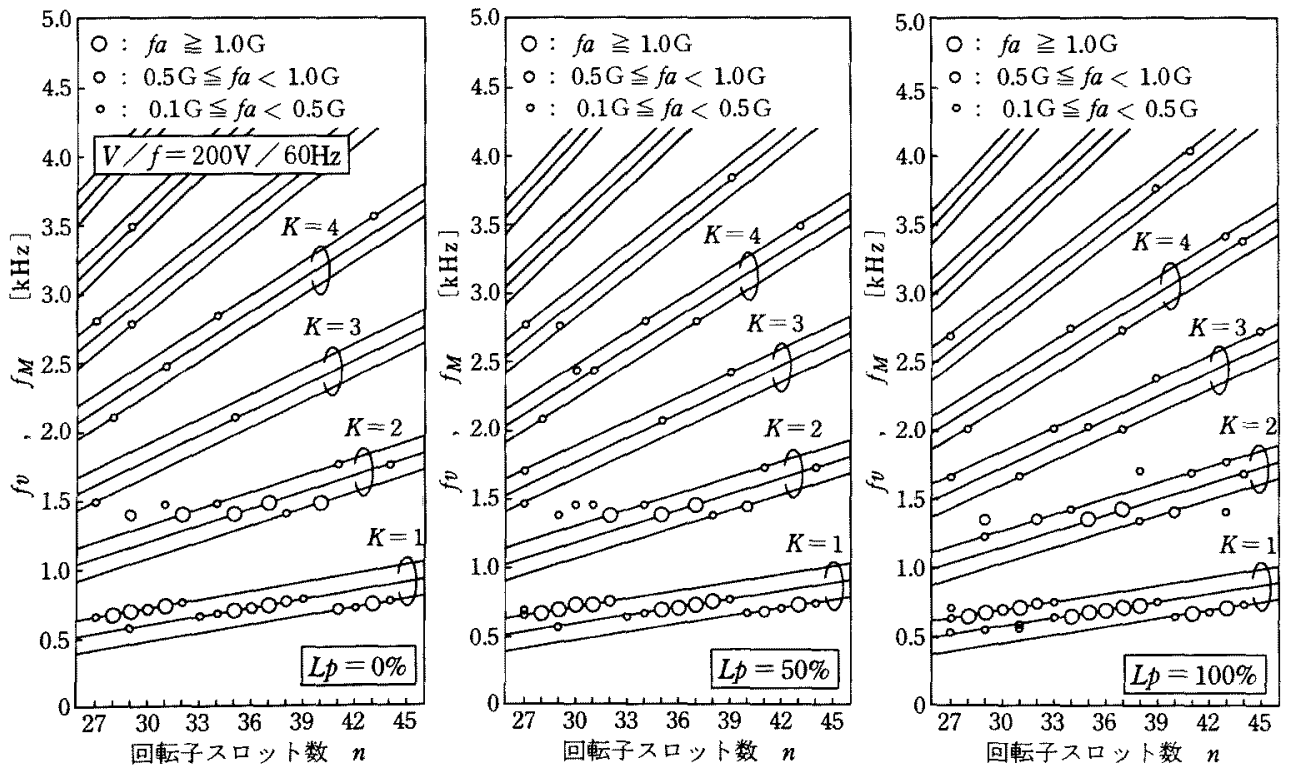

(b) 6 極 IM $\left(p^{\prime}=3\right)$

図4 回転子スロット数による電磁振動の特徽

Fig. 4. Features of the electromagnetic vibration vs. rotor slots. 
表4 顕著な電磁振動の発生原因と特徵 $\left(p^{\prime}=2\right)$

Table 4. Causes and characteristics of dominant electromagnetic vibration $\left(p^{\prime}=2\right)$.

\begin{tabular}{|c|c|c|c|c|c|c|c|c|c|c|c|c|}
\hline \multirow[b]{2}{*}{$n$} & \multirow{2}{*}{$\begin{array}{c}f v \\
{[\mathrm{~Hz}]}\end{array}$} & \multicolumn{3}{|c|}{$f a[G]$} & \multicolumn{8}{|c|}{ 主原因となる電磁力波 } \\
\hline & & $L p=0 \%$ & $50 \%$ & $100 \%$ & \multicolumn{2}{|c|}{ 力波の分類 } & $L$ & $K$ & $v_{s}$ & $v_{r}$ & $M$ & 備考 \\
\hline \multirow{2}{*}{27} & \multirow{2}{*}{$11.5 f n$} & \multirow{2}{*}{0.07} & \multirow{2}{*}{0.18} & \multirow{2}{*}{1.41} & 0 & {$[1]$} & \multirow{2}{*}{1} & \multirow{2}{*}{1} & -10 & \multirow{2}{*}{$\begin{array}{c}11 \\
2\end{array}$} & \multirow{2}{*}{1} & \multirow{2}{*}{$v_{e}=-10$} \\
\hline & & & & & & [II] & & & -1 & & & \\
\hline & $125 \mathrm{fm}$ & 031 & 067 & 120 & (1) & [1] & & 1 & -10 & 9 & 1 & \\
\hline & $12.0 / n$ & 0.31 & 0.67 & 1.20 & (1) & [I] & 1 & 1 & -3 & 2 & 1 & $v_{e}=-10$ \\
\hline 29 & & & & & & {[]$_{7}$} & & & -10 & -12 & & $v e^{\prime}=-10$ \\
\hline & $29.0 \mathrm{fn}$ & 1.01 & 143 & 134 & (2) & & 2 & 2 & 14 & 16 & 2 & $v_{e}=14$ \\
\hline & & & & & & [II] & & & 4 & 2 & & $\nu e^{\prime}=-10$ \\
\hline & & & & & & & & & 0 & 2 & & $v_{e}^{\prime}=14$ \\
\hline 30 & $17.0 \mathrm{fn}$ & 1.19 & 1.48 & 2.00 & (3) & [1] & 1 & 1 & 2 & -4 & 2 & \\
\hline & & & & & & [II] & & 1 & -4 & 2 & & \\
\hline & $175 \mathrm{fm}$ & 107 & 121 & 170 & (3) & [I] & 1 & 1 & 2 & -3 & 1 & \\
\hline & $11.0 \mathrm{~g} n$ & 1.07 & 1.21 & 1.79 & (3) & [I] & 1 & 1 & -3 & 2 & 1 & \\
\hline & $29.0 f n$ & 0.58 & 0.80 & 101 & (1) & [I] & & & -10 & 12 & & $y e^{\prime}=-10$ \\
\hline 31 & & & & & & & & & $\frac{0}{-10}$ & $\frac{2}{-8}$ & & $\nu p^{\prime}=-10$ \\
\hline & $310 f$ & 006 & 0.26 & & & [I] & 2 & 2 & 14 & $\frac{0}{12}$ & 2 & $v_{e}=14$ \\
\hline & $31.0 \mathrm{~m}$ & 0.06 & $0.3 \mathrm{~b}$ & 1.24 & (2) & {$[\pi$} & & & 0 & 2 & & $v_{e}^{\prime}=-10$ \\
\hline & & & & & & [L] & & & 4 & 2 & & $v_{e} e^{\prime}=14$ \\
\hline & & & & & & [I] & 2 & 2 & 2 & -4 & & \\
\hline 33 & $35.0 \mathrm{fn}$ & 1.97 & 2.28 & 2.96 & (3) & [II] & 2 & 2 & -4 & 2 & 2 & \\
\hline & & & & & & {$[\mathrm{I}]$} & & & 2 & 4 & & \\
\hline 34 & $17.0 \mathrm{fn}$ & 0.43 & 1.23 & 270 & (2) & & 1 & 1 & 2 & 0 & 2 & \\
\hline & & & & & & [I] & 1 & 1 & 4 & 2 & 2 & \\
\hline & & & & & & Th & & & 0 & 2 & & \\
\hline & $17.5 f n$ & 0.17 & 1.06 & 2.06 & (2) & LI] & 1 & 1 & 2 & 3 & 1 & \\
\hline 35 & & & & & & [II] & & 1 & 3 & 2 & 1 & \\
\hline 35 & & & & & & {$[\mathrm{I}]$} & & & 2 & 4 & & \\
\hline & $35.0 f n$ & 2.09 & 2.65 & 3.64 & (2) & & 2 & 2 & 2 & 1 & 2 & \\
\hline & & & & & & [II] & & & 4 & 2 & & \\
\hline & & & & & & & & & $\frac{1}{2}$ & $\frac{2}{1}$ & & \\
\hline & $185 \mathrm{fn}$ & 078 & 097 & 163 & 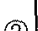 & [1] & & & 2 & 3 & & \\
\hline & $10.0 / n$ & 0.70 & 0.91 & 1.65 & (2) & [ח] & 1 & 1 & 1 & 2 & 1 & \\
\hline & & & & & & & & & 3 & 2 & & \\
\hline 37 & $350 f m$ & $02 ?$ & 060 & 701 & (1) & [I] & 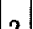 & $?$ & 2 & 0 & 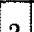 & \\
\hline $3 t$ & $50.0 / n$ & 0.22 & 0.00 & 1.01 & (1) & [II] & 2 & 2 & 0 & 2 & 2 & \\
\hline & & & & & & {$[1]$} & & & 2 & -1 & & \\
\hline & $55.5 f n$ & 0.80 & 1.19 & 0.59 & (2) & & 3 & 3 & 2 & 5 & 3 & \\
\hline & & & & & & [II] & & & -1 & 2 & & \\
\hline & & & & & & & & & $\frac{5}{2}$ & $\frac{2}{0}$ & & \\
\hline 38 & $190 \mathrm{fm}$ & 119 & 120 & 78 & (2) & [1] & & 1 & 2 & 4 & & \\
\hline 30 & $19.0 \mathrm{~m} n$ & 1.19 & 1.20 & 1.18 & (2) & [II] & 1 & 1 & 0 & 2 & 2 & \\
\hline & & & & & & [II] & & & 4 & 2 & & \\
\hline 39 & $17.5 \mathrm{fn}$ & 0.45 & 0.60 & 1.04 & (1) & {$[1]$} & 1 & 1 & 2 & -1 & 1 & \\
\hline & & & 0.00 & & (1) & [II] & 1 & 1 & -1 & 2 & 1 & \\
\hline
\end{tabular}

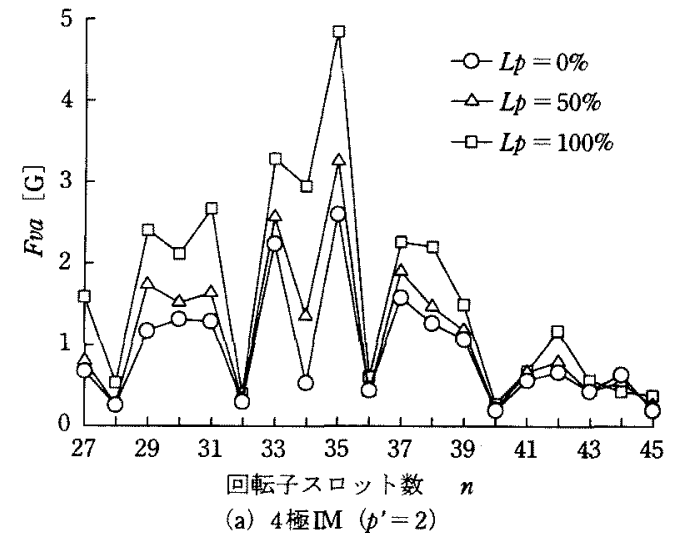

表5 顕著な電磁振動の発生原因と特街 $\quad\left(\phi^{\prime}=3\right)$

Table 5. Causes and characteristics of dominant electromagnetic vibration $\left(p^{\prime}=3\right)$.

\begin{tabular}{|c|c|c|c|c|c|c|c|c|c|c|c|}
\hline \multirow{2}{*}{$n$} & \multirow{2}{*}{$f v[\mathrm{~Hz}]$} & \multicolumn{3}{|c|}{$f a[\mathrm{G}]$} & \multicolumn{7}{|c|}{ 主原因となる霞磁力波 } \\
\hline & & $L p=0 \%$ & $50 \%$ & $100 \%$ & & 50分類 & $L$ & $K$ & $v s^{\prime}$ & $v_{r}^{\prime}$ & $\bar{M}$ \\
\hline \multirow[b]{2}{*}{28} & \multirow{2}{*}{$11.3 f n$} & \multirow{2}{*}{1.66} & \multirow{2}{*}{1.43} & \multirow{2}{*}{1.70} & \multirow{2}{*}{ (3) } & {$[I]$} & \multirow{2}{*}{1} & \multirow{2}{*}{1} & 3 & -5 & \multirow[b]{2}{*}{2} \\
\hline & & & & & & [II] & & & -5 & 3 & \\
\hline \multirow{2}{*}{29} & \multirow{2}{*}{$11.7 f n$} & \multirow{2}{*}{2.86} & \multirow{2}{*}{2.91} & \multirow{2}{*}{3.30} & \multirow{2}{*}{ (3) } & {$[I]$} & \multirow{2}{*}{1} & \multirow{2}{*}{1} & 3 & -2 & \multirow[b]{2}{*}{1} \\
\hline & & & & & & [II] & & & -2 & 3 & \\
\hline \multirow{2}{*}{31} & $123 \mathrm{fm}$ & 141 & 155 & 178 & (3) & {$[\mathrm{I}]$} & 1 & 1 & 3 & -2 & 1 \\
\hline & $12.0 \mathrm{~g} n$ & 1.41 & 1.05 & 1.10 & (3) & [I] & 1 & 1 & -2 & 3 & 1 \\
\hline & $233 \mathrm{fm}$ & & & & (1) & [I] & 2 & & 3 & -5 & \\
\hline 32 & $23.3 \mathrm{~m}$ & 1.30 & 1.12 & 0.94 & (1) & [II] & 2 & 2 & -5 & 3 & 2 \\
\hline & & & & & & {$[1]$} & & & 3 & 5 & \\
\hline 34 & $11.3 f n$ & 0.28 & 0.20 & 1.00 & (2) & & 1 & I & 3 & 1 & 2 \\
\hline & & & & & & [II] & & & 5 & 3 & \\
\hline & & & & & & & & & 1 & 3 & \\
\hline & & & & & & {$[\mathrm{I}]$} & & & 3 & 4 & \\
\hline & $11.7 \mathrm{fn}$ & 1.69 & 2.46 & 3.27 & (2) & & 1 & 1 & 3 & 2 & 1 \\
\hline & & & & & & [П]] & & & 4 & 3 & \\
\hline 35 & & & & & & & & & 2 & 3 & \\
\hline & & & & & & [I] & & & 3 & 5 & \\
\hline & $23.3 f n$ & 1.32 & 1.53 & 1.76 & (2) & & 2 & 2 & 3 & 1 & 2 \\
\hline & & & & & & {$[\pi]$} & & & 5 & 3 & \\
\hline & & & & & & [I] & & & $\frac{1}{2}$ & $\frac{3}{2}$ & \\
\hline 36 & $12.0 f n$ & 0.97 & 1.08 & 1.20 & (2) & {$[\pi]$} & 1 & 1 & 3 & 3 & 0 \\
\hline & & & & & & {$[$ [I] } & & & 3 & 3 & \\
\hline & & & & & & [I] & & & 3 & 2 & \\
\hline & $12.3 f n$ & 2.80 & 2.94 & 3.08 & (2) & & 1 & 1 & $\frac{3}{2}$ & $\frac{4}{3}$ & 1 \\
\hline 37 & & & & & & [II] & & & 4 & 3 & \\
\hline Ji & & & & & & {$[\mathrm{T}]$} & & & 3 & 1 & \\
\hline & $24.7 \mathrm{fn}$ & 1.91 & 147 & 103 & (2) & {$[1]$} & 2 & 2 & 3 & 5 & 2 \\
\hline & & & & & & [ח] & & 2 & 1 & 3 & 2 \\
\hline & & & & & & & & & 5 & 3 & \\
\hline & & & & & & [I] & & & 3 & 1 & \\
\hline 38 & $12.7 f n$ & 0.87 & 1.19 & 1.12 & (2) & & 1 & 1 & 3 & 5 & 2 \\
\hline & & & & & & [II] & & & 1 & 3 & \\
\hline & & & & & & {$[\mathrm{I}]$} & & & $\frac{3}{3}$ & $\frac{3}{-5}$ & \\
\hline 40 & $24.7 f n$ & 1.27 & 0.74 & 0.53 & (1) & [II] & 2 & 2 & 3 & $\frac{-3}{2}$ & 2 \\
\hline & 71 & & & & & [I] & & & 3 & -2 & \\
\hline 41 & $11.7 f n$ & 0.73 & 0.84 & 1.36 & (1) & [II] & 1 & 1 & -2 & 3 & 1 \\
\hline 42 & $123 \mathrm{fm}$ & 114 & 125 & 165 & (1) & {$[\mathrm{I}]$} & $\pi$ & 1 & 3 & -4 & 7 \\
\hline 45 & $12.0 / n$ & 1.14 & 1.35 & 1.65 & (1) & [II] & 1 & 1 & -4 & 3 & 1 \\
\hline
\end{tabular}

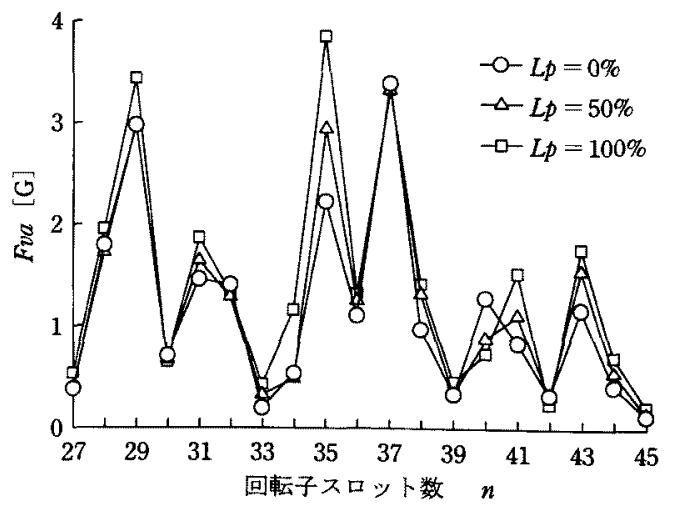

(b) 6 極 IM $\left(p^{\prime}=3\right)$

図5回転子スロット数に上る全実効值の変化

Fig. 5. Measured overall of the electromagnetic vibration with rotor slot. 
なる回転子を組合せた場合，および6極IMに極対数の倍数 となる回転子を組合せた場合，Fvaは相対的に小さい傾向 にある。しかし，6極IMの場合，Lpに対するFvaの增大の 割合は，各回転子スロット数によりさまざまである。前述 のように，6極IMにおいては無負荷時には固有振動数近辺 に多数の顕著な電磁振動を生じる。しかし，負荷の増加に 伴い，電磁力波の発生周波数が固有振動数から遠ざかるた ぬ，振動加速度が減少する振動成分が多い。従って，6極 $\mathrm{IM} の$ 場合，4極IMに比べ，Lpを增加するとFvaが減少する スロット数組合せが多くなったものと考えている。

〈4.2〉電磁振動に及ほす斜めスロットの影製図6 に，測定結果の一例として, $n=35, L p=100 \%$ に扔ける電 磁振動に及ぼす斜めスロットの効果を示す。同図より明ら かなように， $n=35$ では，顕著な振動成分として， $17.5 \mathrm{fn}$ 成分, $35 \mathrm{fn}$ 成分および52.5 fnn成分を生びている。また， こ

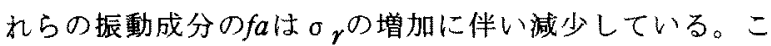
れらの振動成分発生の主原因は，いずれも表1の分類(2)の 電磁力波であると考えられる。

図7に，Lpおよび $\sigma_{r} に$ 対する， $n=27$ おび35における 顕著な振動成分の $f a$ の変化を示す。同図より明らかなよう に，n=27における11.5 f $n$ 成分およびn=35における $17.5 \mathrm{fn}$

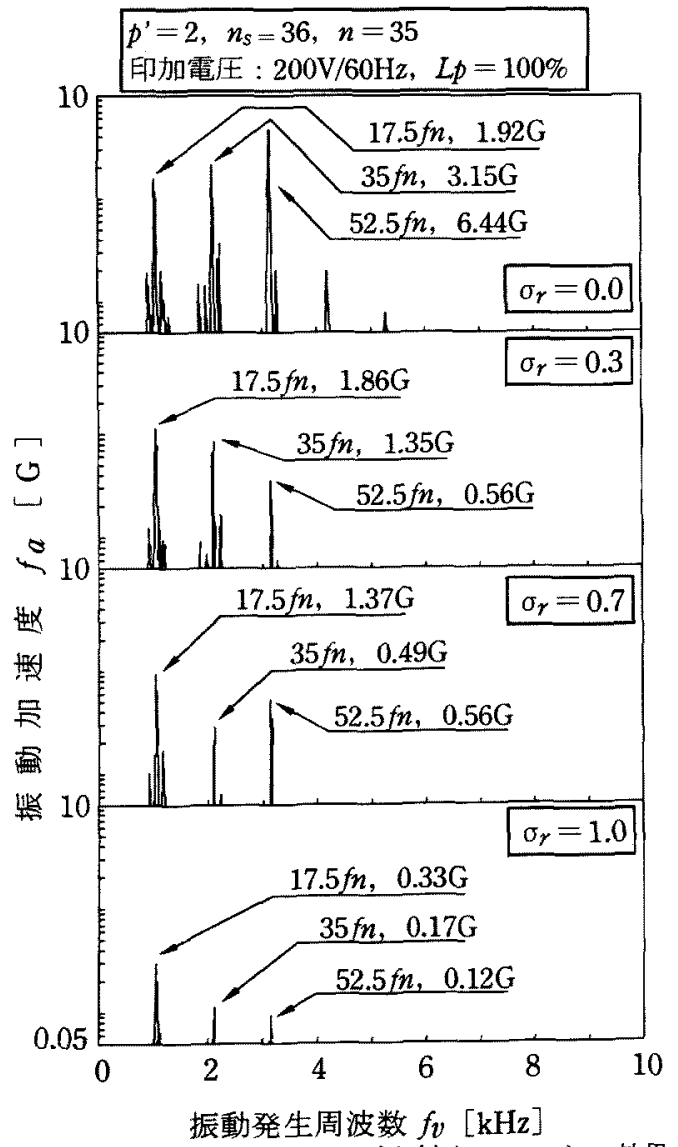

図 6 顕著な電磁振動に及ぼす斜めスロットの効果

Fig. 6. Effect of skewed slot on the dominant electromagnetic vibration.

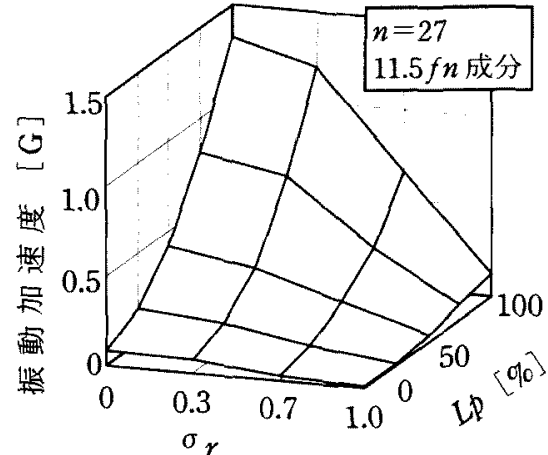

(a) $n=27,11.5 f n$ 成分

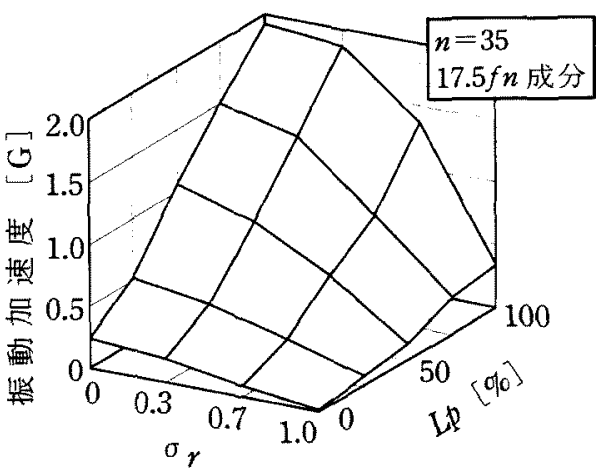

(b) $n=35,17.5 f n$ 成分

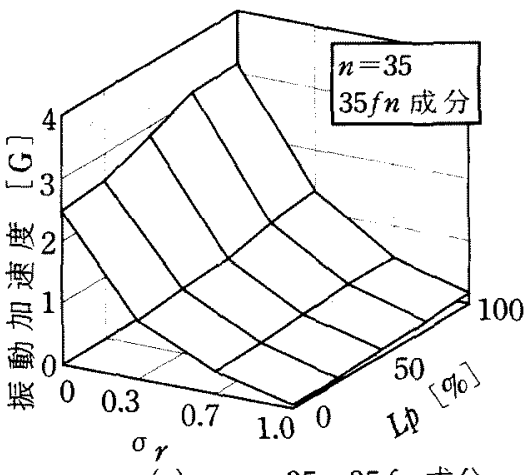

(c) $n=35,35 f n$ 成分

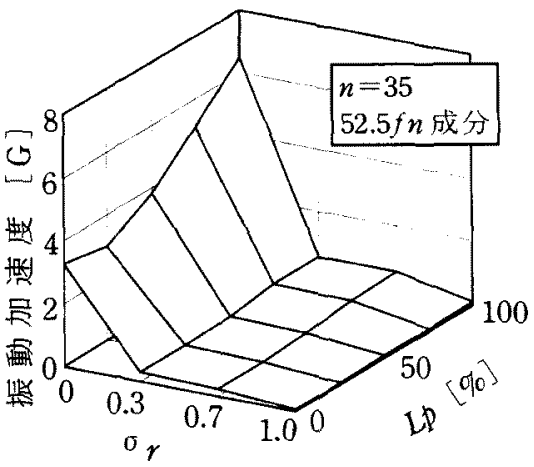

(d) $n=35,52.5 f n$ 成分

図7電磁振動に対する斜めスロットの効果

Fig. 7. The effect of skewed slot on the electromagnetic vibration. 
成分は Lpの增加とともに著しく增大している。他の2つの 振動成分注無負荷時にも影著であり，Lpを变えてもそのfa

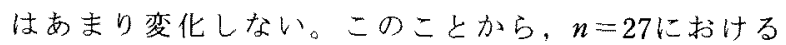
$11.5 f n$ 成分およびn=35における17.5 fn成分の発生原因は主 として表1の電磁力波 [曰] であり，他の2つの振動成分の 発生原因は主として電磁力波 [ I ] であると考えられる。 斜めスロットを施すことにより，いずれの振動成分の $f a$ も 負荷状態に関わらず減少しており， $\sigma_{\gamma}$ を大きくると の減少割合も大きい傾向にある。

表6に，図7に示した顕著な振動成分の $\sigma_{r}$ に対する减少 割合および主原因となる高調波次数の斜めスロット係数な

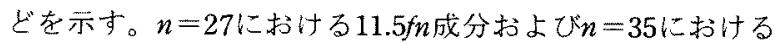
$17.5 f n$ 成分の発生の主原因性電磁力波 [II] と考えられる ので，前述の理論より，n=27の11.5fn成分では，回転子 スロット高調波の次数 $v_{q}{ }^{\prime}=25$ 次および29次, $n=35$ にお ける17.5fn成分では， $v_{q}^{\prime}=33$ 次就よひ37次の斜めスロッ 卜係数の絶対值にほほ比例して減少しているものとみなせ る。これに対して，35 fn成分および52.5 fn成分の発生の主 原因は電磁力波 [I ] と考えられるので, 発生の主原因と なる固定子スロット高調波の次数 $v_{p}{ }^{\prime}=70$ 次および74次, および106次および110次の斜めスロット倸数の絶対值にそ れぞれほぼ比例して减少しているものと見なせる。また， 発生原因となる高調波次数が高いほど，。原対する振動 成分の $f a$ の減少割合は大きい。例えば, $L p=100 \%, \sigma_{r}=$ $0.3 の$ 場合, $\sigma_{r}=0.0$ に対して $n=35$ D $17.5 \mathrm{fn}$ 成分の $\mathrm{fa}$ 97\%，52.5 fn成分のfaは9\%に減少しており，主原因上なる 高調波次数が高いほど小さな斜めスロット角で大きな減少 効果を得ている。なお，図7 (d)および表6より明らかな 上うに, 52.5 fnn成分のfaは, $\sigma_{r}=0.3$ の場合と $\sigma_{r}=0.7$ の場 合とでほぼ同じ大きさとなっている。これは106次および 110次調波の斜めスロット係数より明らかなように，斜め スロット係数に依存していることが原因と考えられる。

\section{5. あとがき}

本論文においては，IMの負荷時に生じる電磁力波およ び電磁振動発生状況に及ぼす極数, スロット数組合せおよ び斜めスロットの影響について，理論的㧍よび実験的に考 察した。その結果をまとめると，以下のようである。

（1） 4 極IMに極数の倍数となる回転子を組合せた場 合，負荷を増加した場合においても顕著な電磁振動を生じ ない傾向にある。また，これらの回転子を除く極対数の倍 数となる回転子老組合せた場合，第1次スロット高調波に よるモードの小さな電磁力波により顕著な電磁振動を生じ る傾向にある。

（2）6極IMに極対数の倍数となる回転子を組合せた場 合，負荷を增加した場合においても特に影著な電磁振動を 生じない傾向にある。しかし，本論文で用いた供試機にお いては, 機械系の共振の影響により顕著な電磁振動を生じ る場合もある。

（3） 4 極IMの場合，振動加速度の全実効値は，回転子
表 6 斜めスロットによる隇少効果と斜めスロ ット係数との比較 $\left(p^{\prime}=2, n_{S}=36\right)$

Table 6. Relation between measured electromagentic vibration and skew reduction factor.

\begin{tabular}{|c|c|c|c|c|c|c|c|}
\hline$n$ & fo & & 0.0 & 0.3 & 0.7 & 1.0 & 備考 \\
\hline \multirow{7}{*}{27} & \multirow{7}{*}{$\frac{5}{5}$} & $0 \%$ & $\begin{array}{l}0.09 \mathrm{G} \\
(100 \%)\end{array}$ & $\begin{array}{c}0.07 \mathrm{G} \\
(83 \%)\end{array}$ & $\begin{array}{c}0.03 \mathrm{G} \\
(35 \%)\end{array}$ & $\begin{array}{c}0.01 \mathrm{G} \\
(10 \%)\end{array}$ & \multirow{5}{*}{ 実測值 } \\
\hline & & $25 \%$ & $\begin{array}{l}0.19 \mathrm{G} \\
(100 \%)\end{array}$ & $\begin{array}{c}0.15 \mathrm{G} \\
(79 \%)\end{array}$ & $\begin{array}{c}0.07 \mathrm{G} \\
(38 \%)\end{array}$ & $\begin{array}{c}0.01 \mathrm{G} \\
(3 \%)\end{array}$ & \\
\hline & & $50 \%$ & $\begin{array}{c}0.412 \mathrm{G} \\
(100 \%)\end{array}$ & $\begin{array}{c}0.34 \mathrm{G} \\
(82 \%)\end{array}$ & $\begin{array}{c}0.19 \mathrm{G} \\
(46 \%)\end{array}$ & $\begin{array}{c}0.04 \mathrm{G} \\
(9 \%)\end{array}$ & \\
\hline & & $75 \%$ & $\begin{array}{l}0.81 \mathrm{G} \\
(100 \%)\end{array}$ & $\begin{array}{c}0.71 \mathrm{G} \\
(88 \%)\end{array}$ & $\begin{array}{l}0.36 \mathrm{G} \\
(45 \%)\end{array}$ & $\begin{array}{c}0.09 \mathrm{G} \\
(11 \%)\end{array}$ & \\
\hline & & $100 \%$ & $\begin{array}{l}1.32 \mathrm{G} \\
(100 \%)\end{array}$ & $\begin{array}{l}1.20 \mathrm{G} \\
(91 \%)\end{array}$ & $\begin{array}{l}0.66 \mathrm{G} \\
(50 \%)\end{array}$ & $\begin{array}{c}0.13 \mathrm{G} \\
(10 \%)\end{array}$ & \\
\hline & & $\left|K_{s 25}\right|$ & $100 \%$ & $88 \%$ & $44 \%$ & $8 \%$ & \multirow{2}{*}{$\begin{array}{l}\text { 斜めス吅 } \\
\text { ット䌽数 }\end{array}$} \\
\hline & & $\mid K_{\mathrm{S} 29}$ & $100 \%$ & $84 \%$ & $30 \%$ & $7 \%$ & \\
\hline & \multirow{7}{*}{$\stackrel{5}{5}$} & $0 \%$ & $\begin{array}{l}0.24 \mathrm{G} \\
(100 \%) \\
\end{array}$ & $\begin{array}{c}0.21 \mathrm{G} \\
(86 \%)\end{array}$ & $\begin{array}{c}0.10 \mathrm{G} \\
(40 \%)\end{array}$ & $\begin{array}{c}0.02 \mathrm{G} \\
(9 \%)\end{array}$ & \multirow{5}{*}{ 実測值 } \\
\hline & & $25 \%$ & $\begin{array}{l}0.51 \mathrm{G} \\
(100 \%)\end{array}$ & $\begin{array}{c}0.43 \mathrm{G} \\
(83 \%)\end{array}$ & $\begin{array}{c}0.26 \mathrm{G} \\
(50 \%)\end{array}$ & $\begin{array}{c}0.08 \mathrm{G} \\
(16 \%)\end{array}$ & \\
\hline & & $50 \%$ & $\begin{array}{l}1.06 \mathrm{G} \\
(100 \%)\end{array}$ & $\begin{array}{c}0.88 \mathrm{G} \\
\{83 \%\}\end{array}$ & $\begin{array}{c}0.56 \mathrm{G} \\
(53 \%)\end{array}$ & $\begin{array}{c}0.13 \mathrm{G} \\
(13 \%)\end{array}$ & \\
\hline & & $75 \%$ & $\begin{array}{l}1.50 \mathrm{G} \\
(100 \%)\end{array}$ & $\begin{array}{c}.35 \mathrm{G} \\
(90 \%)\end{array}$ & $\begin{array}{c}0.83 \mathrm{G} \\
(55 \%)\end{array}$ & $\begin{array}{l}0.30 \mathrm{G} \\
(20 \%)\end{array}$ & \\
\hline & & $100 \%$ & $\begin{array}{l}1.92 \mathrm{G} \\
(100 \%) \\
\end{array}$ & $\begin{array}{c}1.86 \mathrm{G} \\
(97 \%) \\
\end{array}$ & $\begin{array}{l}1.37 \mathrm{G} \\
(71 \%)\end{array}$ & $\begin{array}{l}0.33 \mathrm{G} \\
(17 \%)\end{array}$ & \\
\hline & & $\left|K_{\mathrm{s} 33}\right|$ & $100 \%$ & $87 \%$ & $42 \%$ & $6 \%$ & \multirow{2}{*}{$\begin{array}{l}\text { 斜め不 } \\
\text { ット保数 }\end{array}$} \\
\hline & & $\mid K_{s 37}$ & $100 \%$ & $84 \%$ & $31 \%$ & $5 \%$ & \\
\hline \multirow{7}{*}{35} & \multirow{7}{*}{ 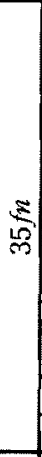 } & $0 \%$ & $\begin{array}{l}2.48 \mathrm{G} \\
(100 \%)\end{array}$ & $\begin{array}{c}0.95 \mathrm{G} \\
(38 \%)\end{array}$ & $\begin{array}{c}0.39 \mathrm{G} \\
(16 \%)\end{array}$ & $\begin{array}{c}0.07 \mathrm{G} \\
(3 \%)\end{array}$ & \multirow{5}{*}{ 実測檤 } \\
\hline & & $25 \%$ & $\begin{array}{l}2.54 \mathrm{G} \\
(100 \%)\end{array}$ & $\begin{array}{l}1.03 \mathrm{G} \\
(40 \%)\end{array}$ & $\begin{array}{c}0.41 \mathrm{G} \\
(16 \%)\end{array}$ & $\begin{array}{c}0.09 \mathrm{G} \\
(3 \%)\end{array}$ & \\
\hline & & $50 \%$ & $\begin{array}{l}2.85 \mathrm{G} \\
(100 \%) \\
\end{array}$ & $\begin{array}{l}1.10 \mathrm{G} \\
(39 \%)\end{array}$ & $\begin{array}{l}0.45 \mathrm{G} \\
(16 \%)\end{array}$ & $\begin{array}{c}0.11 \mathrm{G} \\
(4 \%)\end{array}$ & \\
\hline & & $75 \%$ & $\begin{array}{l}3.11 \mathrm{G} \\
(100 \%)\end{array}$ & $\begin{array}{l}1.26 \mathrm{G} \\
(40 \%)\end{array}$ & $\begin{array}{c}0.49 \mathrm{G} \\
(16 \%)\end{array}$ & $\begin{array}{c}0.13 \mathrm{G} \\
(4 \%)\end{array}$ & \\
\hline & & $100 \%$ & $\begin{array}{l}3.15 \mathrm{G} \\
(100 \%)\end{array}$ & $\begin{array}{l}1.35 \mathrm{G} \\
(43 \%)\end{array}$ & $\begin{array}{c}0.49 \mathrm{G} \\
(15 \%)\end{array}$ & $\begin{array}{c}0.17 \mathrm{G} \\
(5 \%)\end{array}$ & \\
\hline & & $\left|K_{s 70}\right|$ & $100 \%$ & $50 \%$ & $22 \%$ & $0 \%$ & \multirow{2}{*}{$\begin{array}{l}\text { 斜めス保数 } \\
\text { \% }\end{array}$} \\
\hline & & $\left|K_{s 74}\right|$ & $100 \%$ & $46 \%$ & $21 \%$ & $5 \%$ & \\
\hline & \multirow{7}{*}{$\begin{array}{l}5 \\
\text { L } \\
\text { î } \\
\text { î }\end{array}$} & $0 \%$ & $\begin{array}{l}3.24 \mathrm{G} \\
(100 \%) \\
\end{array}$ & $\begin{array}{c}0.30 \mathrm{G} \\
(9 \%)\end{array}$ & $\begin{array}{c}0.29 \mathrm{G} \\
(9 \%)\end{array}$ & $\begin{array}{c}0.08 \mathrm{G} \\
(2 \%)\end{array}$ & \multirow{5}{*}{ 実測值 } \\
\hline & & $25 \%$ & $\begin{array}{l}2.99 \mathrm{G} \\
(100 \%)\end{array}$ & $\begin{array}{l}0.33 \mathrm{G} \\
(11 \%)\end{array}$ & $\begin{array}{l}0.29 \mathrm{G} \\
(10 \%)\end{array}$ & $\begin{array}{c}0.08 \mathrm{G} \\
(3 \%)\end{array}$ & \\
\hline & & $50 \%$ & $\begin{array}{l}3.79 \mathrm{G} \\
(100 \%) \\
\end{array}$ & $\begin{array}{c}0.41 \mathrm{G} \\
(11 \%) \\
\end{array}$ & $\begin{array}{c}0.36 \mathrm{G} \\
(9 \%) \\
\end{array}$ & $\begin{array}{c}0.07 \mathrm{G} \\
(2 \%)\end{array}$ & \\
\hline & & $75 \%$ & $\begin{array}{l}5.08 \mathrm{G} \\
(100 \%) \\
\end{array}$ & $\begin{array}{l}0.55 \mathrm{G} \\
(11 \%) \\
\end{array}$ & $\begin{array}{c}0.51 \mathrm{G} \\
(10 \%)\end{array}$ & $\begin{array}{c}0.08 \mathrm{G} \\
(2 \%) \\
\end{array}$ & \\
\hline & & $100 \%$ & $\begin{array}{l}6.44 \mathrm{G} \\
(100 \%) \\
\end{array}$ & $\begin{array}{c}0.56 \mathrm{G} \\
(9 \%) \\
\end{array}$ & $\begin{array}{c}0.56 \mathrm{G} \\
(9 \%) \\
\end{array}$ & $\begin{array}{c}0.12 \mathrm{G} \\
(2 \%) \\
\end{array}$ & \\
\hline & & $\left|K_{s 106}\right|$ & $100 \%$ & $10 \%$ & $6 \%$ & $1 \%$ & \multirow{2}{*}{$\begin{array}{l}\text { 斜め石 } \\
\text { ット保数 }\end{array}$} \\
\hline & & $\mid K_{s 110}$ & $100 \%$ & $6 \%$ & $9 \%$ & $4 \%$ & \\
\hline
\end{tabular}

( )内は, $\sigma_{r}=0.0$ の振動加速度に対寸る比率 
スロット数が極数の倍数となる場合に相対的に小さくなる ことを明らかにした。また，6極IMに極対数の倍数となる 回転子を組合せた場合, Fvaは相対的に小さくなることも 実験的に明らかにした。

（4）回転子を斜めスロットとした場合, 電磁力波 [ I ] が発生の主原因となる電磁振動は, その発生の主原 因となる固定子磁束の高調波次数の斜めスロット倸数の絶 対值にほぼ比例して减少する。電磁力波 [I] が発生の主 原因となる電磁振動は, その発生の主原因となる回転子磁 束の高調波次数の斜めスロット係数の絶対值にほぼ比例し て減少する。

本論文で明らかにした事柄が, IMの負荷時の電磁振動 および電磁騒音を勘案したスロット数組合せ並びに斜めス ロット角の決定に有用な基礎的資料になれば望外の幸せで ある。

最後に, 本論文を作成するに当たり, 種々のご援助, ご 鞭撻を賜った 侏東芝 石橋文徳氏 (現, 芝浦工業大学) 並びに同 望月資康氏, また, 膨大な実験結果の整理など にご協力いただいた中部大学大学院工学研究科博士前期課 程 室町和弘氏（現, 松下精工侏), 同 片山晴義氏, 中部 大学工学部電気工学科卒業研究生に梁甚なる感謝の意を表 します。また, 電気学会回転機研究会などの席上にて有益 なるご討論をいただいた方々に梁く感謝します。

(平成10年10月 26 日受付, 平成 11 年 4 月 15 日再受付)

\section{文献}

(1) P. L. Alger : "The Magnetic Noise of Polyphase Indution Motors", AIEE, 73, 451 (1954)

（2）石崎彰:「かご形誘導電動機の振動及び騒音につい て」電学誌, 75, 800, 451 (昭30-5)

(3) S. J. Yang : "Low-noise electrical motor", Clarendon Press, Oxford, 1981

(4) F. Ishibashi, S. Noda : "Frequencies and Modes of Electromagnetic Vibration of a Small Induction Motor", T.IEE Japan, 116D, 11, 1110 (平7-11)

（5）廣塚功・坪井和男：「かご形誘導電動機のスロット数 組合せによる電磁振動の実験的考察」電学論, 109D，5，347 (平元 -5 )

（6）坪井和男・廣堟功・石橋文徳：「かご形誘導電動機の 負荷時における電磁振動の発生原因と特徵」, 電学 論, $117 \mathrm{D}, 1,73$ (平9-1)

（7）廣塚功·室町和弘・坪井和男・石橋文徳：「かご形誘導 電動機の負荷時電磁振動に及ぼすスロット数組合せの 影響に関する一考察」電気学会回転機研資, $\mathrm{RM}-97-33$ (平9-6)

(8) I. Hirotsuka, K. Tsuboi, F. Ishibashi ; "Effect of
Slot-Combination on Electromagnetic Vibration of Squirrel-Cage Induction Motor under Loaded Condition", PCC-Nagaoka, 843 (1997-8)

（9）廣塚 功・坪井和男・石橋文徳：「かご形誘導電動機の 負荷時電磁振動に及ぼす斜めスロットの影響に関する 実験的考察」電気学会回転機研資, RM-97-114（平 9-9)

(10) I. Hirotsuka, K. Tsuboi, F. Ishibashi ; "Effects of Skewed Slots on the Electromagnetic Vibration of A Squirrel-Cage Induction Motor under Loaded Conditions", PCIM'98, 379, (1998-4)

（11）廣塚功・坪井和男・中村敬就・石橋文徳：「かご形誘 導電動機の高調波電圧による電磁振動発生に関する考 察」, 電学論, $1130,3,394$ (平5-3)

（12）蓮見孝雄：「籠形誘導電動機に於ける斜溝の影響」 電学誌, 58, 604, 944 (昭13-11)

（13）坪井和男·秋山勇治·安林幹翁·加藤邦弘：「誘導電 動機の電流特性に及ぼす回転子スロット数の影響」電 学誌, 98B, 12, 987 (昭53-12)

（14）坪井和男·秋山勇治：「誘導電動機の始動時異常卜 ルク特性に関する実験的考察」電学論，106B，8, 106 (昭58-8)

（15）室町和弘・廣塚功・坪井和男・石橋文徳:「三相かご形 誘導電動機の負荷時の電磁振動の全実効値に及ぼす回 転子スロット数の影響」1995電気関倸学会東海支連 大, №.224

廣塚功 （正員）1961年8月29日生。1986年3月中部

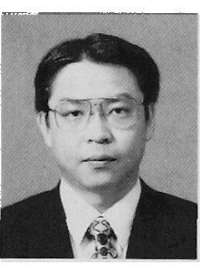
大学大学院工学研究科電気工学専攻博士前 期課程終了。同年 4 月三菱電機侏入社。同 年10月同社退社。平成 2 年 3 月中部大学大学 院工学研究科電気工学専攻博士後期課程満 期退学。同年4月同大学助手, 1996年4月同 助教授, 現在に至る。工博。1997年電気設 備学会学術部門論文奨励賞受賞。電気設備学会, IEEE会 員。

坪井和男（正員）1944年4月11日生。1973年3月中部

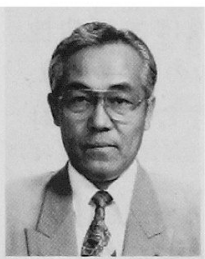
工業大学 (現, 中部大学) 大学院工学研究 科電気工学専攻修士課程終了。同大学講 師, 助教授を経て, 1984年4月中部大学教 授, 現在に至る。主として, 誘導電動機お よび同期電動機の解析と特性改善に関する 研究に従事。工博 (九州大学)。1981年電 気学会電気学術振興賞論文賞受賞。IEEE会員。 